\title{
Halal Harmonization Development Opportunities: a Literature Study
}

\section{Peluang Pengembangan Harmonisasi Halal: Studi Literatur}

\begin{tabular}{l}
\hline Author \\
\hline Hamzah robbani \\
Kolej Universiti Islam Antarbangsa \\
Selangor
\end{tabular}

\section{Duconomics} Sci-meet

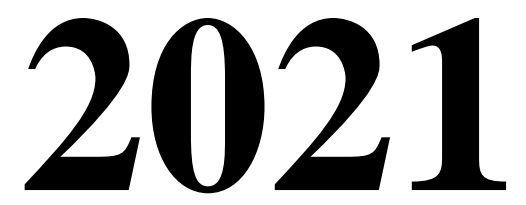

VOLUME 1

JULI

\begin{tabular}{ll}
\hline Page & \\
& $427-434$ \\
\hline DOI
\end{tabular}

10.37010/duconomics.v1.5489

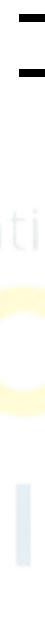

\section{Abstract}

This study aims to examine the literature related to halal, especially how halal is in Indonesia. This study uses qualitative methods with literature study analysis techniques.

Researchers use a basic research approach to raise halal issues that can become opportunities and threats for the development of the halal sector. The researcher applies a systematic literature review (SLR). the result Halal issues are widely discussed in research both at home and abroad. Researchers used Emerald as the primary reference source and developed a meta-analysis protocol by structuring the literature as follows Global Halal Industry Halal Certification, Centralization halal hub, Halal certification,

Halal Harmonization, Level of knowledge, Halal Tourism, Halal Food, Halal Cargo, Halal during Pandemic Covid -19. Keywords

Global halal issue, Halal Certification, Halal Harmonization, Systematic literature review

Abstrak

Penelitian ini bertujuan untuk mengkaji literatur terkait kehalalan, khususnya bagaimana kehalalan di Indonesia.

Penelitian ini menggunakan metode kualitatif dengan teknik analisis studi literatur. Peneliti menggunakan pendekatan penelitian dasar untuk mengangkat isu-isu halal yang dapat menjadi peluang dan ancaman bagi perkembangan sektor halal. Peneliti menerapkan sistematik literature review (SLR). hasilnya Isu halal banyak dibahas dalam penelitian baik di dalam maupun di luar negeri. Peneliti menggunakan Zamrud sebagai sumber referensi utama dan mengembangkan protokol meta-analisis dengan menyusun literatur sebagai berikut Sertifikasi Halal Industri Halal Global, Sentralisasi

halal hub, sertifikasi Halal, Harmonisasi Halal, Tingkat pengetahuan, Wisata Halal, Makanan Halal, Kargo Halal, Halal di masa Pandemi Covid -19

\begin{tabular}{l}
\hline Kata kunci \\
\hline $\begin{array}{l}\text { Isu halal global, Sertifikasi Halal, Harmonisasi Halal, Tinjauan literatur } \\
\text { sistematis }\end{array}$
\end{tabular}


Syazwan (2014) explained that the Government should encourage more international relations among AFTA countries to raise Halal logistics to a higher level. Halal market potential reaches 2 trillion USD even according to other sources; the global Halal Industry as a whole is estimated to be worth around USD 2.3 trillion (excluding Islamic finance) per year. Three main factors, namely First support the fast growth of the halal market, the Muslim population is quite large and grows at 1.8 percent per year, Second, the growing economic growth and thus increasing purchasing power among Muslims. The last is the emergence of the potential for the halal market in non-Muslim countries and halal industry players (Azam \& ABDULLAH, 2020).

In 2016, the distribution of halal products had a reasonably large market share, as explained in the following diagram

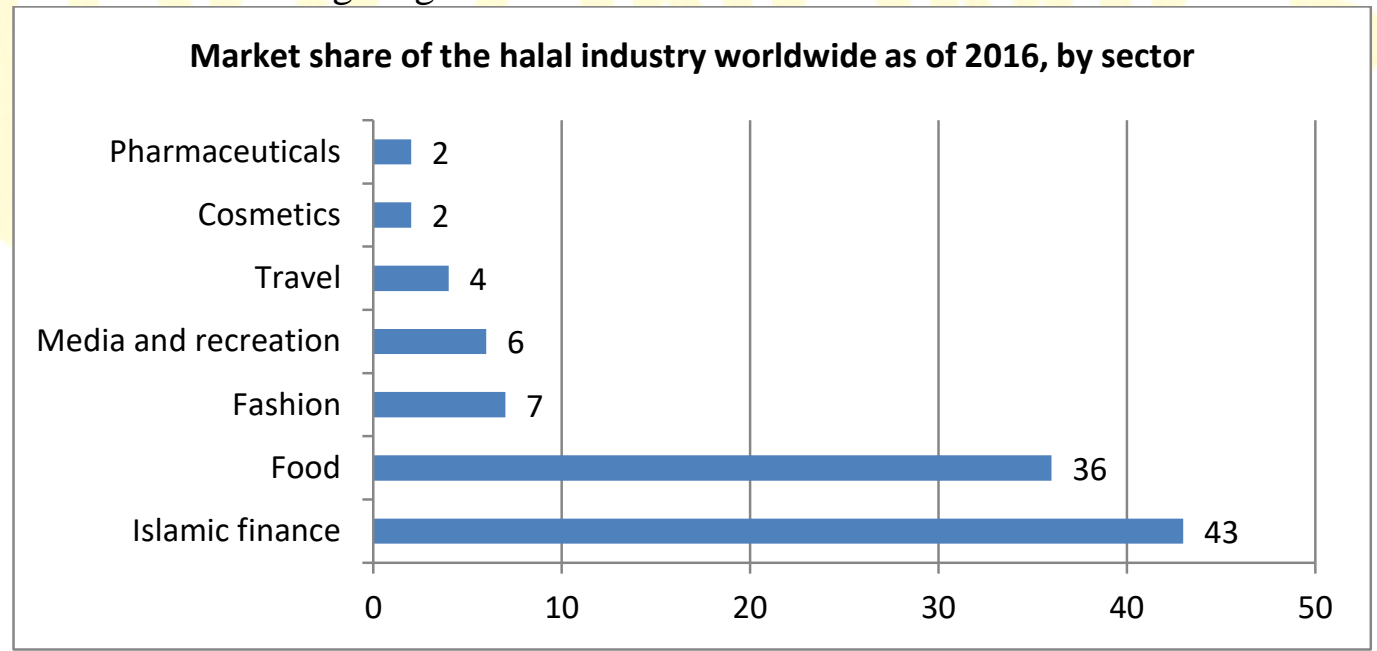

The chart above shows the market share of the worldwide halal industry as of 2016 by sector. In that year, the halal food sector accounted for $36 \%$ of the total global halal market, while halal cosmetics held $2 \%$ of the market share. This is increasing along with the market value of Muslim food and beverages globally

market there is around. worth 2 billion USD and has the potential to grow to approximately 3.08 billion dollars by 2022 , as described in the following table

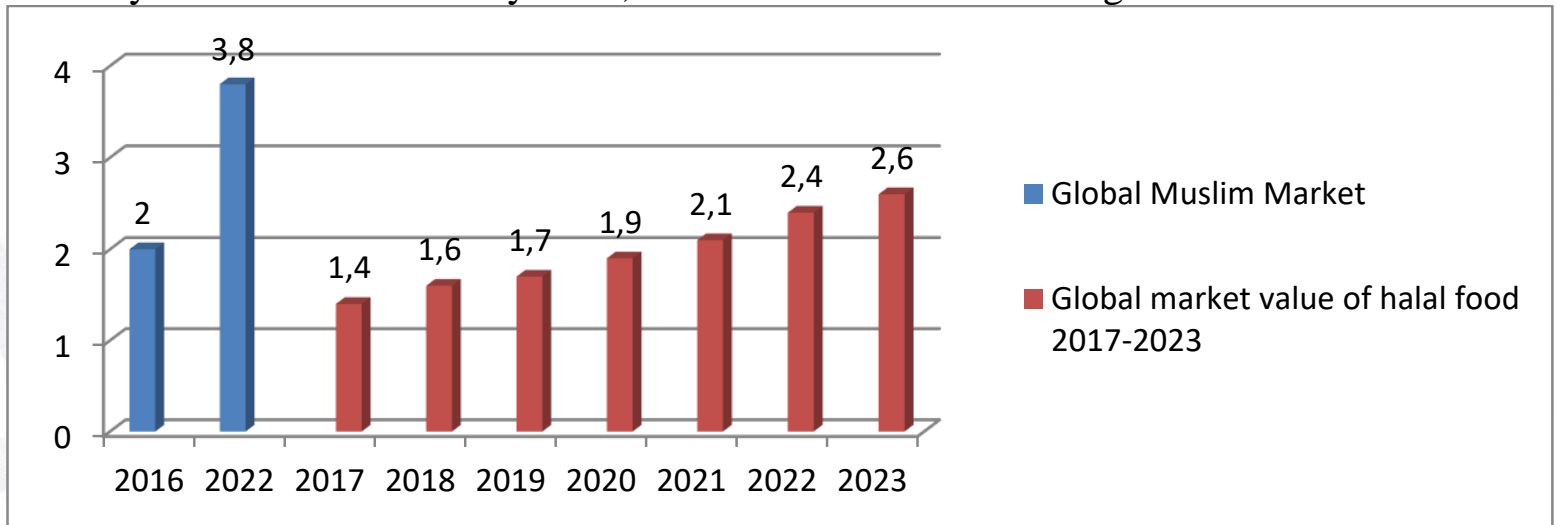

In addition to the global Muslim market, the table also shows the market value of halal food worldwide in 2017 and provides forecasts for 2018 to 2023. According to the report, halal food has a global market value of approx. 1.4 trillion USD in 2017 and is expected to reach 2.6 trillion USD by 2023 .

In contrast to Indonesia, the challenge of becoming a global halal hub in Indonesia focuses on three points including; 1 . Minority responses related to food exclusivity that can occur from 12\% of minorities in Indonesia, 2. Regulation of Law No. 33 of 2014 concerning the guarantee of halal products, which in expert opinion prefers the Syafii sect, is very strict in implementing halal standards. This threatens the flexibility of the 
halal market that will enter Indonesia, 3. Smaller SMEs such as street vendors do not get added value and are not ready to comply with regulations that require business actors to have halal certificates. In addition, they see that the halal certification only gives them difficulties while not adding new value to their business. (Hasyim, 2019)

with problems in the development of the halal hub, each country will be joint repair can be done when bilateral cooperation or multilateral in the development of the halal hub. This is supported by research conducted by (Borzooei \& Asgari, 2013) that the essential requirement, according to experts, is to believe that a country must consider vital needs such as human capital and infrastructure and establish relationships with various countries around the world.

Globally, the halal economy is expected to grow steadily and offers excellent opportunities for Indonesia and Malaysia, which already have a relatively established and competitive halal industry. Even so, each Member State has its strengths in developing the Halal economy. However, industrial growth is also hampered by a lack of capacity and capacity, especially among SMEs. There is a need to improve demanddriven products and services in quality, price, brand, taste, and nutrition facts. There is also a need to improve accessibility to raw materials, skilled and semi-skilled workers, and financing. IB 2017-2021 advocates for the Member States to build on each other's strengths to enter the growing Halal market, such as knowledge sharing and best practices, technology transfer, developing cross-border value chains, and accepting Halal standards. (Waterhouse, 2017)

Competition in managing the halal market shows a contradiction. Although developed countries have several Muslims, the market share for halal food is high. Governments with fewer Muslim populations, namely Thailand, UK, and Australia, can seize opportunities for halal food in the global market. Thus, most of the halal food exporters come from these non-Muslim countries. (Nurrachmi, 2017)

Other problems arise when the change in stakeholder positions, the condition of politics of social particular organizational sub-committee of tourism, organization Concern Tourism, and the Federation of Agents Travel Universal adopt the standard kosher established. However, due to changes in the direction of political and social organizations, it no longer has a continuity in the conduct of activities to promote tourism kosher when rating Muslim greatly needed. (Luxchaigul et al., 2016)

This study raises current issues related to halal. In particular, Indonesia has issued government regulation no. 39 of 2021 regarding the implementation of the halal product guarantee sector. This regulation is an effort by the government to regulate the halal sector more specifically. One of the points regulated in government regulation no 39 of 2021 is the organizer of halal product guarantees. This is important because until now each Muslim country has different standards in recognizing halal products. This research also wants to initiate the possibility of recognition of international halal standards. The absence of mutual recognition of halal standards between countries has resulted in several things including: inefficient and ineffective export and import processes between countries due to double halal standards (Zhan et al., 2016), the difficulty of consumers in choosing halal tourism due to the absence of harmonious halal promotion and awareness between countries (Aziza et al., 2020).

\section{METHOD}

This study uses qualitative methods with literature study analysis techniques. Researchers use a basic research approach to raise halal issues that can become opportunities and threats for the development of the halal sector. The researcher applies 


\section{0}

Merdeka Belajar dan Tantangan Ekonomi dalam Menyongsong Era Society 5.0

a systematic literature review (SLR). SLR is a research method to identify, evaluate and interpret all relevant research results related to research questions, topics, or phenomena of concern (Kitchenham, 2004). According to Perry \& Hammodn (Anggraeni et al., 2004), the steps taken in the SLR are 1. They are identifying research questions 2 and developing a meta-analysis research protocol. 3. Determining the location of the research database 4 and selecting relevant research results 5 and selecting research results according to the topic and quality 6. Extracting data from individual studies 7 . Synthesizing research results 8 . Presenting research results in research reports on metaanalysis results.

\section{RESULT AND DISCUSSION}

(Azam \& ABDULLAH, 2020) first explain about Global Halal Industry: Realities And Opportunities. This paper attempts to examine the current realities of the global halal industry by observing the factors determining such increasing demand for Halal industry in addition to the opportunities that are offered fromrecent global development in the market. To achieve the objectives of the study, a methodology of analyzing secondary data from different sources was adopted in this paper. The findings show that there are three major factors driving the rapidly growing global halal market. First, sizable and growing Muslim population at 1.8 per cent per annum, Second, growing economic development and hence increasing purchasing power among the Muslim. The last is the emergence of potential halal market in non-Muslim nations and halal industry players.

Halal industry also needs to be centralized with the development of halal hub (Borzooei \& Asgari, 2013) explained in his research entitled Establishing a Global Halal Hub: In-Depth Interviews. The purpose of study is to explore the requirements needed for a country to establish itself as a global Halal hub. With exploratory research paper uses a semi-structured in- depth interview to obtain the perceptions of Halal experts about the requirements for establishing a Halal hub. The results of the study indicate that human capital, media, research and development, events, country's capability, public and governmental support, marketing strategy, and infrastructure comprise the vital requirements.

Halal hub should also be integrated with halal certification. There is a strong role for government. (Hasyim, 2019) conducted a study by reviewing State Law No. 33/2014 on Halal Product Assurance is to be enacted in October 2019. That Indonesia has some challenge of becoming a global halal hub in Indonesia focuses on three points including; 1. Minority responses related to food exclusivity that can occur from $12 \%$ of minorities in Indonesia, 2. Regulation of Law No. 33 of 2014 concerning the guarantee of halal products, which in expert opinion prefers the Syafii sect, is very strict in implementing halal standards. This threatens the flexibility of the halal market that will enter Indonesia, 3. Smaller SMEs such as street vendors do not get added value and are not ready to comply with regulations that require business actors to have halal certificates. In addition, they see that the halal certification only gives them difficulties while not adding new value to their business.

(Pamukcu \& Sariisik, 2021) research for Suggestions for standardization of halal tourism in hospitality industry. The purpose of this paper is to determine the expectations of hotel guests regarding the halal standards in the hotels where they stay. Besides, the determination of differences in demographic characteristics of the participants is among the objectives of the research. Quantitative research methods were used in this research. Owing to the lack of a specific scale in the related literature, 
the questionnaire used in the study was created as a result of pilot tests conducted with the expressions mentioned in the theoretical studies. Analysis methods were decided by considering the preconditions for parametric test techniques. This reseach finds that Islamic lifestyle is specified as the most common reason for choosing halal concept hotels. Additionally, there are some other outstanding reasons like halal food, safer holiday, The emergence of sufficient tourism facilities will show that this group will be respected and valued. Hence, this will also contribute positively to social tolerance.

Khan et al., (2019) has researched how harmonization of halal can be done, in his research entitled Using integrated weighted IRP-Fuzzy TISM approach towards evaluation of initiatives to harmonise Halal standards has an objectivesuggest initiatives to facilitate harmonisation of Halal standards as to eliminate trade barrier of Halal and to assure the availability of Halal consumables to larger masses. With Ranking of the initiatives for the harmonisation of Halal standards taking in consideration the costs of accomplishment and associated benefits obtained has been done through the application of integrated Interpretive Ranking Process (IRP) and Fuzzy Total Interpretive Structural Modelling (Fuzzy TISM). This integrated methodology with the weighted criteria have refined the value of the net dominance of different variables, thereby increasing the efficacy of IRP in decision making. the results of this study suggest that strengthening the strategic coordination and collaboration among competent HCBs is a significant initiative

B. Othman et al., (2016) explained about the level of knowledge in his research entitled Evaluation of knowledge, halal quality assurance practices and commitment among food industries in Malaysia. Objective of this research is to assess the level of knowledge, halal dietary quality assurance practices, and commitment among food industries in the implementation of halal in Malaysia. Besides, the study was based on two categories that are considered major contributors in the chain of halal food sector in Malaysia which are the multinational, and small medium enterprise (SME). The sample of the study was comprised of 241 companies from halal certification holders (MNCs 1/4 69; SMEs 1/4 172). Cross-sectional study through random sampling and purposive sampling was used where the internal halal committee who have been specifically appointed in the organization were asked to fill in the questionnaire. Personally hand-delivered questionnaires in workplaces was used as a method of data collection. The data were analyzed using SPSS version 21. Based on the analysis, it was found that the level of knowledge, halal quality assurance practices and commitment to be at a good level. Whereas the results of inference showed that there are significant differences for the three variables studied.

what halal industry can be standardized, starting from several sectors that can be harmonized,Mohd Nawawi et al., (2020) Nawawi explain how halal food developed in Thailand. research that has an objective The paper aims to explore the development of the halal industry in Thailand. It endeavours to investigate the main factors behind the country's success as one of the largest exporters of halal-certified foods and products in the Southeast Asian region, in spite of the fact that Thailand is a non-Muslim-majority country. Only 4.3 per cent of the 69 -million population of Thailand is Muslims. , qualitative research method was adopted. This paper used structured literature study by analyzing various subjects of halal about Thailand's halal sector. At the same time, several in-depth interviews with the corresponding halal authorities in Thailand and site visits were also conducted. We also undertook observations in several sites in Thailand to analyze the issue further. Nawawi Finding that $t$ the strong presence of Thailand in the global halal industry is because of its bustling tourism industry that helps to bolster 
Merdeka Belajar dan Tantangan Ekonomi dalam Menyongsong Era Society 5.0 the country's halal branding, its uniformity of halal definition and standards, and adequate support to the local SMEs.

(Abdul Rahman et al., 2018) Rahman raised different things, namely halal cargo. With research, title Implementing air cargo halal warehouse: insight from Malaysia. This study aims to discuss the challenges in implementing halal warehouses in the air cargo context and the standard handling process for the storage of halal products for import and export purposes. This is vital to ensure that halal products do not get contaminated and comply with halal logistics standards throughout the supply chain process. The method was used by an exploratory study by adopting a single case study to understand better the definition of halal warehouse, the challenges in implementing halal warehouse, and the standard handling process for the storage at the warehouse for import and export purposes. A well-guided case study protocol is followed. this reseach finding that - Five categories have found to be the main challenges in implementing halal warehouse. They are coded as halal product trade, halal asset and facility, halal standard of procedure, human factor and perspectives between logistics provider and halal agencies. With regard to the standard handling process for import and export purposes in the airgo context with compliance to Shariah at the halal warehouse, there are seven main steps involved for import and nine steps involved for export.

Previous research was also supported by (Zailani et al., 2017) with the title of the research Halal logistics opportunities and challenges. The paper aims to investigate the challenges and opportunities for logistics companies in Malaysia to adopt halal logistics. Logistics plays a key role in protecting the halal integrity of halal food through proper transportation, storage, and handling along the supply chain until it reaches its final destination. This research builds on existing research published in the Journal of Islamic Marketing on halal logistics. In addition to an extensive literature review, five focus group discussions were conducted to discover the challenges and opportunities concerning halal logistics services in Malaysia. The results show that the future market demands and the competitive opportunities related to halal services are the primary motivators of first movers in halal logistics. The early adopters of halal logistics face several challenges such as ambiguous halal guidelines, lack of international halal certification, lack of collaboration among governing agencies (i.e., logistics service providers (LSPs), Jabatan Kemajuan Islam Malaysia (JAKIM), and Halal Industry Development Corporation), a lack of cost-effective standards, an overly competitive transportation sector, lack of demand, lack of halal logistics compulsion, financial challenges and a general misunderstanding of halal practices.

The two studies above are also related to the findings from (Khan et al., 2021), with research that aims to identify 11 critical factors towards effective management of a Halal supply chain (HSC) and provides a framework for the HSCM by evaluating Halal practices' impact on sustainability performance measures empirically, - A structured questionnaire-based survey has been carried out to collect data for analysis. The statistical analysis is accomplished by exploiting the merits of factor analysis and structural equation modeling (SEM). The results imply that out of 11 critical factors, nine factors on effective management of the HSC are statistically significant, and the impacts of two critical factors are positive but statistically insignificant. In the structural model, the path coefficient of all success indicators is positive and statistically significant. In terms of the path coefficient of sustainable performance measures of HSC, all three dimensions, economic, environmental and social, are positive and statistically significant.

Despite being hit by the COVID-19 pandemic, the halal industry must continue to grow. Research conducted by Hidayat et al. (2021) analyzes the Halal industry before, during, and after the COVID-19 outbreak. Qualitative content analysis derived from a 
narrative-type literature review - supported by expert opinions elicited from semistructured interviews and transcripts from the keynotes of five prominent speakers at a Halal industry conference during the pandemic. The conference theme covered the Halal industry's development and strategies before, during, and after the COVID-19 outbreak. There are opinions, concerns, and actionable suggestions from the five prominent guests on how the Halal industry is faced with challenges and new opportunities, with the potential to lead an agenda toward community and transparency.

\section{CONCLUSION}

Researchers summarized at least 11 articles related to halal. Halal issues are widely discussed in research both at home and abroad. Researchers used Emerald as the primary reference source and developed a meta-analysis protocol by structuring the literature

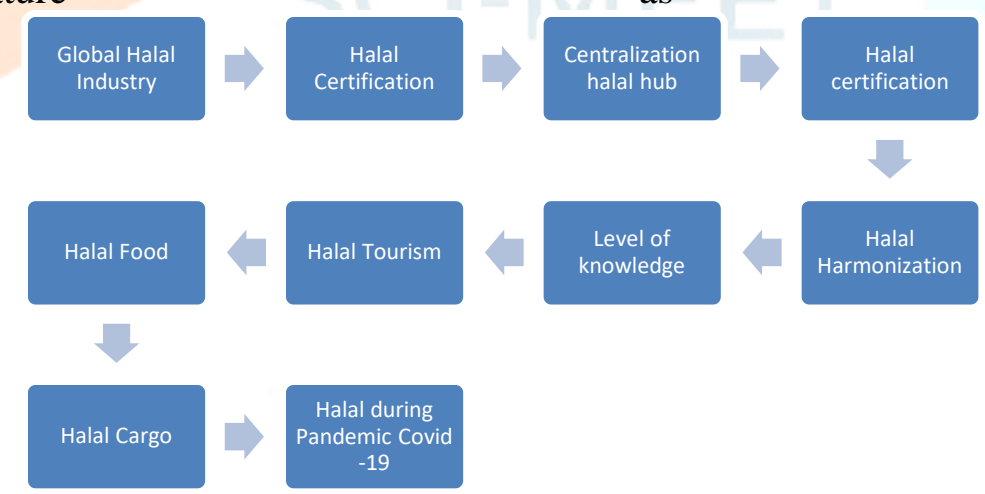
follows

From the articles cited, the researcher found a synthesis of the development of the halal sector from time to time. Previously only centered on halal food, then developed on halal tourism, supply chain, to halal fashion. This is important to harmonize with the appropriate regulations to be certified and harmonized so that mutual recognition of the halal sector between countries can be implemented.

\section{BIBLIOGRAPHY}

Abdul Rahman, N. A., Mohammad, M. F., Abdul Rahim, S., \& Mohd Noh, H. (2018). Implementing air cargo halal warehouse: insight from Malaysia. Journal of Islamic Marketing, 9(3), 462-483. https://doi.org/10.1108/JIMA-09-2016-0071

Azam, M. S. E., \& ABDULLAH, M. A. (2020). Global Halal Industry: Realities and Opportunities. International Journal of Islamic Business Ethics, 5(1), 47. https://doi.org/10.30659/ijibe.5.1.47-59

Aziza, N., Prasnowo, M. A., \& Hidayat, K. (2020). Halal Tourism, Cerfication Regulation, and Research Institute Insigh From IMT-GT Countries: A Review. International Journal of Science, Technology \& Management, 1(3), 265-272. file://C:/Users/LENOVO/Downloads/52-Article Text-273-1-10-20200930.pdf

Borzooei, M., \& Asgari, M. (2013). Establishing a Global Halal Hub: In-Depth Interviews. International Journal of Academic Research in Business and Social Sciences, 3(10), 168181. https://doi.org/10.6007/ijarbss/v3-i10/288

Hasyim, S. (2019). Becoming a Global Halal Hub: Is Indonesia Ready? (Issue 098). https://think-asia.org/handle/11540/10374

Hidayat, S. E., Rafiki, A., \& Nasution, M. D. T. P. (2021). Halal industry's response to a current and post-COVID-19 landscape and lessons from the past. Journal of Islamic Marketing. https://doi.org/10.1108/JIMA-06-2020-0180 
Merdeka Belajar dan Tantangan Ekonomi dalam Menyongsong Era Society 5.0

Khan, M. I., Haleem, A., \& Khan, S. (2021). Examining the link between Halal supply chain management and sustainability. International Journal of Productivity and Performance Management. https://doi.org/10.1108/IJPPM-07-2019-0354

Khan, M. I., Khan, S., \& Haleem, A. (2019). Using integrated weighted IRP-Fuzzy TISM approach towards evaluation of initiatives to harmonise Halal standards. Benchmarking, 26(2), 434-451. https://doi.org/10.1108/BIJ-04-2018-0086

Luxchaigul, N., Bunnag, S., \& Malyarom, M. (2016). Study and Improvement of Halal Travel Routes linked to Neighboring Countries under the Indonesia-Malaysia-Thailand Growth Triangle: IMT-GT. Abac Odi Journal Vision. Action. Outcome., 3(2), 1-9. http://www.assumptionjournal.au.edu/index.php/odijournal/article/view/2289

Mohd Nawawi, M. S. A., Abu-Hussin, M. F., Faid, M. S., Pauzi, N., Man, S., \& Mohd Sabri, N. (2020). The emergence of halal food industry in non-Muslim countries: a case study of Thailand. Journal of Islamic Marketing, 11(4), 917-931. https://doi.org/10.1108/JIMA05-2018-0082

Nurrachmi, R. (2017). The Global Development of Halal Food Industry: A Survey. Tazkia Islamic Finance and Business Review, 11(1), 41-56.

Othman, B., Shaarani, S. M., \& Bahron, A. (2016). Evaluation of knowledge, halal quality assurance practices and commitment among food industries in Malaysia. British Food Journal, 118(8), 2033-2052. https://doi.org/10.1108/BFJ-12-2015-0496

Pamukcu, H., \& Sariisik, M. (2021). Suggestions for standardization of halal tourism in hospitality industry. Journal of Islamic Marketing, 12(2), 389-407. https://doi.org/10.1108/JIMA-04-2019-0078

Syazwan Ab Talib, M., Bakar Abdul Hamid, A., Hafiz Zulfakar, M., \& Jeeva, A. S. (2014). Halal logistics PEST Analysis: The Malaysia perspectives. Asian Social Science, 10(14), 119-131. https://doi.org/10.5539/ass.v10n14p119

Waterhouse, B. Y. J. (2017). Implementation blueprint 2017-2021 (Issue March, pp. 4-9).

Zailani, S., Iranmanesh, M., Aziz, A. A., \& Kanapathy, K. (2017). Halal logistics opportunities and challenges. Journal of Islamic Marketing, 8(1), 127-139. https://doi.org/10.1108/JIMA-04-2015-0028

Zhan, G., Watcharapun, P., \& Wangbenmad, C. (2016). Halal Logistics and Supply Chain Linkage Potential across the Thai-Malaysia Border as a driver of IMT-GT Economic Development. 933-944. 